\title{
The role of estrogen in bone growth and formation: changes at puberty
}

This article was published in the following Dove Press journal:

Cell Health and Cytoskeleton

24 December 2010

Number of times this article has been viewed

\author{
Divya Singh' \\ Sabyasachi Sanyal ${ }^{2}$ \\ Naibedya Chattopadhyay \\ 'Division of Endocrinology, ${ }^{2}$ Division \\ of Drug Target Discovery and \\ Development, Central Drug Research \\ Institute (Council of Scientific \\ and Industrial Research), Lucknow, \\ Uttar Pradesh, India
}

\begin{abstract}
A high peak bone mass (PBM) at skeletal maturity is a good predictor for lower rate of fracture risks in later life. Growth during puberty contributes significantly to PBM achievement in women and men. The growth hormone (GH)/insulin-like growth factor 1 (IGF-1) axis has a critical role in pubertal bone growth. There is an increase in GH and IGF-1 levels during puberty; thus, it is assumed that sex steroids contribute to higher GH/IGF-1 action during growth. Recent studies indicate that estrogen increases GH secretion in boys and girls, and the major effect of testosterone on GH secretion is via aromatization to estrogen. Estrogen is pivotal for epiphyseal fusion in young men and women. From studies of individuals with a mutated aromatase gene and a case study of male patient with defective estrogen receptor-alpha (ER- $\alpha$ ), it is clear that estrogen is indispensable for normal pubertal growth and growth plate fusion. ER- $\alpha$ and estrogen receptor-beta (ER- $\beta$ ) have been localized in growth plate and bone. ER knockout studies have shown that ER- $\alpha^{-/}$female mice have reduced linear appendicular growth, while ER- $\beta^{-/-}$mice have increased appendicular growth. No such effect is seen in ER- $\beta^{-/-}$males; however, repressed growth is seen in ER- $\alpha^{-/-}$males, resulting in shorter long bones. Thus, ER- $\beta$ represses longitudinal bone growth in female mice, while it has no function in the regulation of longitudinal bone growth in male mice. These findings indicate that estrogen plays a critical role in skeletal physiology of males as well as females.
\end{abstract}

Keywords: peak bone mass, puberty, estrogen, growth plate

\section{Introduction}

Osteoporosis is a metabolic bone disorder characterized by low bone mass and microarchitectural deterioration of bone tissue with a consequent increase in bone fragility and susceptibility to fracture. ${ }^{1,2}$ The risk of osteoporotic fracture depends on two factors: the biomechanical strength of bone and the forces applied to it. Bone mass, a measure of bone size and volumetric mineral density, is a determinant of bone strength. Bone mass and strength achieved at the end of growth, also designated as peak bone mass (PBM), play a key role in the risk of osteoporotic fractures occurring later in life. . $^{3,4}$ Skeletal growth is an outcome of complex arrays of sequential as well as overlapping actions of both nongonadal and gonadal hormones. Here, we will discuss the relationship between bone mass and strength in pubertal skeleton, systemic and local effects of growth and sex hormones in regulating skeletal growth, and molecular mechanism of estrogen action in growing skeleton.

Correspondence: Divya Singh

Division of Endocrinology, Central Drug Research Institute (Council of Scientific and Industrial Research), Lucknow, Uttar Pradesh, India

Tel $+9|52226| 24|I-4| 8$ ext 4246

$\mathrm{Fax}+915222623938$

Email divya_singh@cdri.res.in

\section{Characteristics of bone mass and strength in PBM achievement}

Several longitudinal studies tracking the bone mass and strength through childhood and adolescence and mathematical models suggest that modifying PBM have direct 
consequences on skeletal fragility in old age. ${ }^{5,6}$ Individuals achieving a higher PBM in young adulthood are less likely to develop osteoporosis as age-related bone loss ensues, whereas those with low levels are clearly at greater risk. ${ }^{7}$ From the results of epidemiological studies, it is predicted that a $10 \%$ increase in PBM could reduce the risk of fracture by $50 \%$ in postmenopausal women. ${ }^{8}$ However, the relative contributions of PBM and bone loss to the bone mass in aging women or men remain uncertain. There are some estimates suggesting that in aged women (more than 70 years), half of the variance in trabecular bone mineral density (BMD) and one-third of the variance of cortical BMD are due to bone loss. ${ }^{9}$ Therefore, it appears that the early phase of bone loss after menopause is dependent on PBM achievement, whereas later the phase (aging induced) is not.

Biomechanical strength that affords resistance to mechanical loading of bone is determined by several factors including the size of the bone, the amount of bone within the periosteal envelope and its spatial distribution (the microarchitecture and macroarchitecture), and the degree of mineralization and structural organization of the organic matrix. ${ }^{10}$ During growth, increase in areal bone mineral density (aBMD), assessed by dual X-ray absorptiometry, results from increase in bone size, which is well correlated with increments in the amount of mineralized tissue contained within the periosteal envelope. ${ }^{11-13}$ Volumetric BMD (vBMD), determined by high-resolution quantitative computed tomography, allows measurement of cortical thickness, cross-sectional area, polar moment of inertia ${ }^{14}$ and elastic modulus, or stiffness. Determination of vBMD provides improved prediction of bone strength over aBMD and bone mineral content (BMC).

PBM achievement is a prolonged process that starts in the intrauterine life and progresses through the years of growth into young adulthood. Skeleton grows in length, breadth, mass, and volumetric density with the growth of the body. Bone mass and vBMD at birth are similar in female and male. No significant gender difference was apparent before puberty in bone mass of the axial and appendicular skeleton when corrected for age, nutrition, and physical activity. Skeletal size and vBMD are also similar in prepubertal girls and boys. ${ }^{15}$ Before puberty, basal levels of the growth hormone $(\mathrm{GH})$ /insulin-like growth factor 1 (IGF-1) axis support a slow, but continuous, bone growth. Between the onset of puberty and young adulthood, however, bone mass doubles. ${ }^{5,16,17}$

Puberty is commenced by increased pulsatile secretion of Gonadotropin-releasing hormone (GnRH) by the hypothalamus, leading to increases in serum gonadotropins and consequent increases in gonadal secretion of sex steroids. ${ }^{18}$ The onset of puberty corresponds to a skeletal (biological) age of roughly 11 years in girls and 13 years in boys. ${ }^{19,20}$ The rates of increase in statural height and bone remodeling are greatest in early puberty followed by progressive decline. ${ }^{21}$ Consequently, peak vBMD velocity occurs 2 years later, at menarche in girls and late puberty in boys. The growth pattern in boys varies from girls in two ways: boys have two more years of prepubertal growth because of their later onset of puberty than girls, and pubertal growth spurt in boys lasts for 4 years compared to 3 years in girls. . $^{5,16,17}$ These differences widely account for the $10 \%$ greater statural height and the $25 \%$ greater PBM achieved by males.

Periosteal apposition accounts for $95 \%$ of peak cortical thickness achieved during growth in males and $85 \%$ in females. ${ }^{22}$ Endocortical apposition contributes to the remaining $15 \%$ of peak cortical thickness in females so that overall cortical thickness and volumetric density are not different between the two sexes. ${ }^{22}$ Simultaneously, endocortical bone is resorbed to form a medullary canal until puberty. ${ }^{22,23}$ The distribution pattern of accrual of mineral and matrix in growing long bones differs by sex, greater periosteal accrual in boys and endocortical accrual in girls. ${ }^{24}$ As a result of this spatial difference in bone formation, there is greater increase in marrow cavity area for boys compared with girls, which explains greater overall increase in bone dimensions (ie, greater periosteal apposition and endosteal resorption) in boys. ${ }^{25}$ Thus, although cortical thickness is similar in males and females, the cortical bone mass is greater in males because of the greater perimeter of the larger bone. ${ }^{24}$

In case of long bones, there are no tensile stresses or strains along the neutral axis, and the magnitude of the stresses is proportional to their distance from the neutral or long axis of the bone. ${ }^{26}$ Endocortical apposition at puberty accumulates greater bone mass in women nearer the neutral long axis where it confers less bending strength than a comparable amount produced by periosteal apposition. ${ }^{26,27}$ In men, greater cortical apposition takes place further from the neutral axis of the long bone, conferring more strength in bending by the correspondingly larger muscle mass. ${ }^{27}$ In female subjects, bone mineral mass increases more by endosteal than periosteal accrual. ${ }^{28,29}$ In male subjects, the opposite structural modifications are observed with greater increases in periosteal than endosteal apposition resulting in the increment of both external and internal perimeters of the cortical structure. ${ }^{4}$ At the end of 
pubertal maturation, the cortical thickness is greater in male than female subjects.

\section{Role of nutritional factors in PBM achievement}

Nutrition plays an important role in PBM attainment. Variation in intake of certain nutrients by healthy, well-nourished children and adolescents and its role on bone mass accumulation have received considerable attention over the last few years. Protein-calorie malnutrition during childhood can cause growth retardation and decreased formation of cortical bone and, therefore, can interfere with PBM acquisition. ${ }^{30}$ Most studies pertaining to PBM have been focused on the intake of calcium. By providing adequate calcium intake, it has been observed that bone mass gain can be increased during infancy, childhood, and adolescence and thereby optimal PBM can be achieved. ${ }^{4}$ In some observational studies carried out during childhood and adolescence, a positive correlation between dietary calcium and bone mineral mass was reported. ${ }^{31}$ The benefit of supplemental calcium is usually greater in the appendicular than in the axial skeleton. ${ }^{31}$ Thus, in prepubertal children, calcium supplementation is more effective on cortical appendicular bone than on axial trabecular rich bone or on the proximal femur., ${ }^{4,31}$ Of the influences on calcium absorption, the most important is vitamin $\mathrm{D}$, which is necessary for the active transport of calcium across the intestinal mucosa. ${ }^{30}$ Vitamin D stimulates active intestinal absorption of calcium by inducing the synthesis of a calcium-binding protein in intestinal mucosa. ${ }^{30} \mathrm{~A}$ study of vitamin $\mathrm{D}$ receptor knockout mice demonstrated that bone mineralization and turnover were regulated by the dietary $\mathrm{Ca} / \mathrm{P}$ ratios. Increases in the dietary $\mathrm{Ca} / \mathrm{P}$ ratio from 0.5 to 2 increased the amounts of intestinal calcium absorptions and serum calcium levels. Intestinal phosphorus absorptions were inversely related to the dietary $\mathrm{Ca} / \mathrm{P}$ ratios. Serum parathyroid hormone $(\mathrm{PTH})$ levels decreased, and the values of femoral BMC and BMD increased..$^{32}$

Nutritional status is a key regulator of the circulating and tissue IGF system. ${ }^{33}$ IGF-1 mRNA and protein levels decrease in tissues such as the liver and intestine with fasting and are restored with refeeding. ${ }^{33}$ The level of nutrition affects the biological actions of recombinant GH and IGF-1 administration in humans. ${ }^{33}$ IGF-1 exerts an important impact on renal endocrine and transport functions that is essential for bone mineral economy. ${ }^{4}$ IGF-1 receptors are localized in the renal tubular cells and are connected to the production machinery of $1,25(\mathrm{OH})_{2} \mathrm{D}$ and also to the transport system of inorganic phosphate (Pi) localized in the luminal membrane of the tubular cells. ${ }^{4}$ IGF-1 indirectly stimulates the intestinal absorption of $\mathrm{Ca}$ and $\mathrm{Pi}$ by enhancing the production and circulating level of $1,25(\mathrm{OH})_{2} \mathrm{D}$. The extracellular $\mathrm{Ca}-\mathrm{Pi}$ product is increased by IGF-1, coupled with the stimulation of the tubular capacity to reabsorb Pi. IGF-1, through this dual renal action, favors the mineralization of the bone matrix. ${ }^{4}$

\section{Systemic effects of sex steroids on GH/IGF-I axis}

The GH/IGF-1 axis has a critical role in pubertal bone growth. The peak in longitudinal growth velocity is correlated to peak concentrations of $\mathrm{GH} .{ }^{34,35} \mathrm{GH}$ release is similar in boys and girls prior to puberty. ${ }^{34}$ However, the rise in pulse amplitude of $\mathrm{GH}$ is earlier in girls than in boys during puberty. ${ }^{34}$ In the same manner, a rise in IGF-1 is seen earlier in girls in puberty. ${ }^{34}$ Thus, it has been assumed that sex steroids contribute to the higher $\mathrm{GH} / \mathrm{IGF}-1$ action during pubertal growth period. ${ }^{35,36} \mathrm{GH}$ increases growth at puberty through the stimulation of IGF-1 production. ${ }^{37}$ The pulsatile secretion of GH increases by about 1.5-fold to 3-fold during puberty, and this is accompanied with a greater than 3-fold increase in serum IGF-1 levels. In girls, the peak IGF-1 levels occur at 14.5 years, while in boys, the levels peak nearly a year later. ${ }^{38,39}$ The increase in GH secretion during puberty exhibits a sexually dimorphic pattern that parallels the change in growth velocity. An increase in circulating GH levels is seen in girls early in puberty at Tanner breast stage 2 (B2) with peak levels at Tanner breast stage B3-4. Contrary to this, an increase in $\mathrm{GH}$ is seen at later stages in boys with the peak occurring at Tanner genital stage 4 (G4). ${ }^{39}$

Testosterone administration increases $\mathrm{GH}$ secretion in boys, ${ }^{40}$ and estrogen increases $\mathrm{GH}$ secretion in boys and girls. ${ }^{41}$ However, more recent studies have suggested that estrogens also play a role in stimulating GH secretion in boys. ${ }^{42}$ Conversely, human pubertal data have emerged demonstrating that a substantial portion of testosterone's effect is mediated through its aromatization to estrogen by the enzyme aromatase..$^{34,36,43-45}$

Estrogens are responsible for the development of secondary sexual characteristics and play a major role in reproductive function in women. Estrogens are known to have a biphasic effect on pubertal skeletal growth. ${ }^{43}$ Low estrogen concentrations are known to increase the secretion of GH and subsequent IGF-1 synthesis in boys and girls during early puberty. Estrogens initiate the pubertal growth spurt 
and stimulate skeletal growth. Hence, sex steroid-related changes in GH and IGF-1 secretion may impact on bone size and cross-sectional area. ${ }^{43}$

A close cross talk exists between estrogens and $\mathrm{GH}$ in the regulation of growth and development as exemplified in puberty. ${ }^{42}$ Estrogen stimulation of longitudinal growth is largely dependent on pituitary GH and is mediated via the ERs, estrogen receptor-alpha (ER- $\alpha$ ) and estrogen receptorbeta (ER- $\beta)$, which are expressed in the anterior pituitary as well as the hypothalamus. ${ }^{46} \mathrm{~A}$ positive correlation between $\mathrm{GH}$ and estrogen levels is seen in prepubertal girls and boys. ${ }^{47}$ Endogenous estrogen in peripubertal children increases $\mathrm{GH}$ sensitivity. ${ }^{48}$ Estrogen priming for GH-stimulation testing has been shown to augment $\mathrm{GH}$ release in normal adolescents. ${ }^{41}$ Furthermore, there are reports of $\mathrm{GH}$ secretion being reduced when estrogen signaling is blocked. ${ }^{49-52}$ This close interplay between estrogen and GH status is further demonstrated by the strong correlation between estrogen and GH concentrations throughout normal female puberty. ${ }^{53} \mathrm{GH}$ levels are higher in women to than in men. ${ }^{54,55} \mathrm{~A}$ major part of the stimulation of growth by estrogen is through the GH/IGF-1 axis as boys and girls with IGF-1 deficiency (Laron syndrome) do not have a discernible pubertal growth spurt. ${ }^{56}$ Testosterone supplementation also stimulates GH secretion and increases IGF-1 levels in boys. The effect of testosterone is dependent on aromatization to estrogen because treatment of boys with nonaromatizable androgens such as oxandrolone and dihydrotestosterone (DHT) fails to increase GH secretion. ${ }^{57-59}$ This observation is further supported by the studies in pubertal boys and adult men in which the stimulatory effect of testosterone on $\mathrm{GH}$ is abrogated by tamoxifen, an antiestrogen. ${ }^{50,60}$ However, there are reports that nonaromatizable androgens like DHT and oxandrolone increase growth velocity in boys with delayed puberty without any alteration of serum GH/IGF-1. ${ }^{58,61-63}$ This suggests that these nonaromatizable androgens may stimulate growth through other mechanisms, possibly via direct effect on the androgen receptor (AR) within the growth plate cartilage. ${ }^{64}$

\section{Effect of estrogen on the growth plate}

Longitudinal bone growth occurs at the growth plate by endochondral bone formation. There are three principal zones in the growth plate. These are resting, proliferative, and hypertrophic. The resting zone lies adjacent to the epiphyseal bone and contains infrequently dividing chondrocytes, while the proliferative zone contains replicating chondrocytes. The proliferative chondrocytes located farthest from the resting zone stop replicating and enlarge to become hypertrophic chondrocytes. ${ }^{65,66}$ The processes of chondrocyte proliferation, hypertrophy, and cartilage matrix secretion result in chondrogenesis. At the same time, the metaphyseal border of the growth plate is invaded by blood vessels and bone cell precursors that remodel the newly formed cartilage into bone. ${ }^{66}$ The synchronized processes of chondrogenesis and cartilage ossification lead to longitudinal bone growth.

During growth, the growth plate undergoes structural and functional changes. The rate of longitudinal bone growth decreases as a result of decline in chondrocyte proliferation. ${ }^{67}$ As a consequence, there is a decline in the overall growth plate height, proliferative zone height, hypertrophic zone height, size of hypertrophic chondrocytes, and column density (number of chondrocyte columns per 1-mm growth plate width). ${ }^{66,67}$ At the time of sexual maturation, the growth plate is resorbed, and this process termed as epiphyseal fusion terminates longitudinal bone growth. Estrogen is pivotal for epiphyseal fusion in both young men and women. ${ }^{68}$ The key role for estrogen was confirmed with the recognition of two genetic disorders, estrogen deficiency due to mutations in the aromatase gene ${ }^{69}$ and estrogen resistance due to mutations in the ER- $\alpha$ gene. ${ }^{70}$ In both conditions, the growth plate fails to fuse and growth persists into adulthood.

\section{Role of estrogen in female pubertal growth spurt}

The significance of estrogen for the pubertal growth spurt in girls is well known. Studies in patients with disruptive mutations in the AR (androgen insensitivity syndrome [AIS]) have shown that there is complete resistance to endogenous androgen and that the only functional sex steroid receptor is that for estrogen. ${ }^{44,71}$ In AIS patients, a spontaneous pubertal growth spurt takes place with the spurt velocity being equivalent to that in normal girls starting at an appropriate chronological age for girls (ie, earlier than in normal boys), but bone maturation (ie, closure of the long bones and hence mature height) corresponds to that of normal boys rather than normal girls. ${ }^{72}$ The individuals with this genetic disorder have an XY genotype and normal female external genitalia. As a result of aromatization of testicular and adrenal androgen to estrogen and by secretion of estrogen from the testes, ${ }^{44}$ these individuals undergo normal feminization at puberty. Another study provides convincing evidence that it is estrogen and not androgen that is responsible for the female pubertal growth spurt, and epiphyseal maturation occurred in a female patient with aromatase deficiency having high levels of androgens and low estrogens. ${ }^{44,73}$ Despite high androgen levels, the patient had no breast development and no menarche at 
the age of 14 years. The patient was short with a standard deviation score for height as -1.5 and had no growth spurt, and her bone age was delayed (10 years at chronological age 14 years). Replacement with ethinyl estradiol led to a notable decrease in her androgens and increased pubertal growth spurt. ${ }^{44,73}$ Thus, these studies clearly suggest that estrogen alone is sufficient to support normal pubertal skeletal growth in females.

\section{Role of estrogen in male pubertal growth spurt}

Initially, testosterone was believed to play major role in the pubertal growth spurt in boys. ${ }^{74}$ Testosterone is the most important androgen of men, and $95 \%$ of it is secreted by testis. In addition, a large amount of weakly active androgens is secreted by adrenal cortex. Testosterone can act via AR directly or after conversion to DHT by enzyme $5-\alpha$ reductase. Additionally, it is converted to $17 \beta$ estradiol by enzyme P450 aromatase and subsequently can exert its effect via ER- $\alpha$ or ER- $\beta .^{75}$ Increases in androgen levels in prepubertal individuals result in accelerated growth and epiphyseal maturation. However, it was not certain whether these effects are directly mediated via the AR or whether the effects are due to aromatization of androgen to estrogen and therefore ER-mediated. Recent data suggest that estrogen also plays an important role in pubertal growth spurt in males. ${ }^{76}$ This was substantiated by a case study when a patient carrying an inactivating mutation in ER- $\alpha$ was severely osteoporotic having a bone age of 14 years at the chronological age of 28 years. ${ }^{70}$ His epiphyseal growth plates were not fused, and in spite of being an adult, his growth did not stop. Additional evidence supporting a role for estrogen in connection with the fusion of growth plates in both males and females comes from patients carrying inactivating mutations of aromatase P450 (CYP19). Such inactivation blocks the conversion of testosterone to estrogen, and consequently, serum estrogen levels are very low. These patients have open growth plates, immature bones, lack of a pubertal growth spurt, and continued linear growth well into adulthood. ${ }^{69,77}$ However, after estrogen treatment of these patients with aromatase deficiency, rapid bone maturation and fusion of the growth plates occurs, and further, longitudinal bone growth is discontinued. All this evidence points to the important role of estrogen in pubertal growth in males.

\section{Axial versus appendicular skeleton during pubertal growth}

The growth of the appendicular skeleton, for example, the femur, and the axial skeleton as in the case of vertebrae, results from two different processes that are probably regulated by different mechanisms. In the femur, increase in bone length occurs by endochondral ossification at the growth plates, whereas increases in bone width occur by apposition of subperiosteal bone. ${ }^{78}$ In the vertebrae, growth takes place by endochondral ossification, which starts in the central area of the cartilage anlage and expands toward the periphery in all directions. ${ }^{79}$ Because of these subtle differences in the pattern of bone formation, greater cancellous BMD is achieved in the axial skeleton, whereas greater bone size is achieved in the appendicular skeleton.

Appendicular growth is more rapid than axial growth before puberty. ${ }^{80}$ In early puberty, appendicular growth remains constant with no acceleration, whereas axial growth accelerates. ${ }^{7}$ Growth of both regions then decelerates in late puberty. ${ }^{7}$ Both regions contribute relatively equally to height gain, but a greater proportion of trunk length is gained during puberty. ${ }^{81}$ Men have longer legs than women because in men epiphyseal fusion occurs later than women; however, trunk length is similar in both sexes. ${ }^{82}$ Due to greater vertebral size, men have wider vertebrae than women, producing higher spine $\mathrm{aBMD}$, but $\mathrm{vBMD}$ and bone quantity remain comparable between the two sexes. ${ }^{82}$ Both the deceleration in limb growth and the acceleration in trunk growth are partly estrogen dependent, even in males. ${ }^{82}$ This is the likely reason why hypogonadism produces longer leg length and shorter trunk length. ${ }^{82}$

Racial variation has been observed in bone growth. In a pioneering study, no difference was observed in bone density between African American and Caucasian girls in the first, second, or third stage of sexual development based on Tanner scale. ${ }^{82}$ In contrast, vertebral bone density was significantly higher in African American girls than in Caucasian girls at both Tanner stages 4 and $5 .{ }^{82}$ The results of this study, therefore, indicate that the magnitude of the increase in vertebral bone density in girls approaching skeletal maturity was considerably greater in African Americans than in Caucasians of the same age and at the same level of sexual development. ${ }^{83}$ These results strongly suggest that racial differences in bone mass in the axial skeleton in women initially develop during adolescence. ${ }^{83}$ Whether similar differences in vertebral density exist between African American and Caucasian boys remains to be investigated. The factors responsible for the racial differences in cancellous bone density that occur during puberty are unknown. When adjusted for Tanner stage, no correlations were found between sex steroid levels and values for cancellous bone density. ${ }^{78}$ Investigation on the possibility of calciotropic hormones and the calcium homeostasis system 
favoring positive calcium balance in African Americans has yielded equivocal results. ${ }^{84}$ Further studies are required to establish the pattern of racial variation in skeletal growth by taking other racial groups into consideration.

\section{ER signaling in bone cells}

Studies show the direct effect of estrogen on the growth plate in chondrocytes via ER subtypes, ER- $\alpha$ and ER- $\beta{ }^{85-87}$ Both ER- $\alpha$ and ER- $\beta$ are expressed in the growth plate as well as in the bone, suggesting a role for both ER subtypes in the regulation of skeletal homeostasis. ${ }^{86-88}$ AR has also been demonstrated in the growth plate..$^{89,90}$ Recently, a new subtype of ER has been identified, which is membrane ER G-protein-coupled receptor 30 (GPR30). ${ }^{90}$ It was expressed in the growth plate and declined during the progression of puberty, ${ }^{46}$ suggesting that this new receptor might also be involved in the regulation of longitudinal growth. ${ }^{64}$ The expression of GPR30 is localized to the hypertrophic and resting zones, with no expression in the proliferative zone of the epiphyseal growth plate. This limited localization suggests that GPR30 may be involved in specific processes related to chondrogenesis in the epiphyseal growth plate. ${ }^{91}$ Moreover, the downregulation of GPR30 expression during pubertal progression indicates that GPR30 might modulate the responsiveness of epiphyseal cartilage to estrogen at different stages of puberty. ${ }^{91}$ It has been observed that decline in the level of GPR30 expression in the resting zone occurs in parallel in boys and girls, whereas the corresponding decline in the hypertrophic zone occurs earlier in girls, which is similar in the pubertal growth spurt and growth plate fusion, suggesting that GPR30 might be involved in the modulation of pubertal growth. ${ }^{91}$

Initially, it was believed that the effects of estrogen on bone physiology were indirect. ${ }^{92}$ However, detection of ER- $\alpha$ and ER- $\beta$ in bone cells implied direct roles of ERs in bone growth and physiology. A couple of elegant studies by Nakamura et $\mathrm{al}^{93}$ and Krum et $\mathrm{al}^{94}$ attributed the osteoprotective effects of estrogen to its antiosteoclastic effects. Krum et al using ER- $\alpha$ and ER- $\beta$ knockout mice models demonstrated the role of osteoblasts in osteoclast apoptosis via an ER- $\alpha$-dependent induction of osteoblast FasL in response to E2. ${ }^{94}$ ER- $\alpha$ has also been shown to inhibit RANK-L-mediated osteoclast differentiation using monocyte/macrophage osteoclast precursor RAW264.7 cells. $^{95}$ Bone anabolic effects of estrogen have also been documented over the years in primary calvarial osteoblasts, osteoblast cell-lines, and postmenopausal women receiving estrogen replacement therapies. ${ }^{96,97}$ A range of mechanisms have been proposed for the anabolic effects of estrogen that includes regulation of IGF-1 expression where IGF-1 and/or IGFBP-5 seem to be involved in the estrogen-induced modulation of PTH action on osteoblast proliferation and function, ${ }^{98}$ potentiating bone morphogenetic protein-2 (BMP-2) action by directly modulating differentiation of bipotential stromal cells into the osteoblast and adipocyte lineages, causing a lineage shift toward the osteoblast, ${ }^{99}$ and induction of BMP-2 via direct interaction with BMP-2 promoter where $\mathrm{E} 2$ produced a dose-dependent induction of the mouse -2712 BMP-2 promoter activity in cells cotransfected with ER- $\alpha$ and ER- $\beta .{ }^{100}$ However, the precise role of classical ERs in mediating anabolic effects of estrogen in bone is still unclear. Ironically, although catastrophic skeletal effects are associated with loss of estrogen in menopause or gonadectomy, ER- $\alpha$, ER- $\beta$, or double ER knockout (ERKO, BERKO, and DERKO, respectively) mouse models failed to replicate the striking phenotype associated with loss of estrogen. In addition, the modest skeletal effects shown by these mouse models were found to be dependent on age, sex, and genotype of the mouse model used.

\section{ERs and the female skeleton}

The ER knockout models have given an insight into the role of estrogen in longitudinal bone growth. Analytical study of longitudinal bone length in ER knockouts has shown that the role played by the ERs in association with bone length depends on sex and age. ${ }^{101}$ There is decreased appendicular growth in female mice lacking ER- $\alpha$ (ERKO). ${ }^{102,103}$ Two different ERKO models have been generated by Lubahn et al ${ }^{104}$ (ERKOneo2) and Dupont et al (ERKOd3), ${ }^{105}$ and their bone phenotypes were studied. Studies with ERKOd3 mice, considered as ER- $\alpha$-null, ${ }^{106}$ revealed that these mice exhibit a decrease in bone turnover and an increase in trabecular bone volume in female animals; while there was no effect on femoral bone lengths in female mice, these mice revealed a decreased thickness of cortical bone. ${ }^{107}$ In contrast, Tözüm et al, using same animals, reported increased long bone length in females. ${ }^{108}$ ERKOneo2 mice, in contrast, showed clear stimulatory effect of ER- $\alpha$ on bone length in ${ }^{109,110}$ female mice. ${ }^{110-112}$ Further, in females, these mice also exhibited an increase in cortical cross-sectional bone area due to increased radial cortical bone growth after sexual maturation. ${ }^{12,113}$

These apparent differences in data received from two different ERKO mouse models may in part be explained by the presence of a 46-kDa short form of ER- $\alpha$ in ERKOneo2 mice. Although this short form of ER- $\alpha$ lacks the N-terminal AF-1 activation function, it still contains an intact DNA-binding 
domain and C-terminal ligand-dependent activation function 2. This isoform is capable of binding and activating estrogen response element (ERE)-dependent promoters in AF-2-dependent cells and can even display a dominant negative function. ${ }^{114}$ Interestingly, a human patient lacking ER- $\alpha$ carries a mutation at residue 157 of the protein, which would allow the short 46-kDa spliced form of ER- $\alpha$ to be synthesized, ${ }^{114}$ and this mutant ER has been found to have estrogenic activity on ERE in luciferase-driven reporter assays. ${ }^{115}$

However, in female mice lacking ER- $\beta$ (BERKO), there is increased longitudinal femoral bone growth, ${ }^{103,113,116}$ demonstrating an important role for estrogen in the regulation of longitudinal bone growth. BERKO mice were initially created by Krege et $\mathrm{al}^{117}$ at the University of North Carolina (Chapel Hill, NC). In female mice in growing phase, inactivation of ER- $\beta$ showed increased longitudinal bone growth, ${ }^{11-113,118}$ and at 6 months of age, these mice exhibited higher cortical bone content and periosteal circumference, while trabecular bone volume was unchanged in comparison to wild-type animals. ${ }^{113}$ In female mice of 13 months of age, deletion of ER- $\beta$ induced an increased trabecular bone volume associated with a reduced bone resorption and a higher periosteal circumference. ${ }^{118,119}$ Together, these reports suggest that female BERKO mice are protected against agerelated bone loss in both cortical and trabecular bone by decreasing bone turnover. ${ }^{118}$ Interestingly, ER- $\alpha$ expression was found to be elevated ${ }^{113,119}$ in these BERKO animals, indicating that the enhanced level of ER- $\alpha$ may lead to increased sensitivity of the skeleton to estrogen, thus contributing to the protection of age-related bone loss. These observations suggest a repressive function of ER- $\beta$ in counteracting the stimulatory action of ER- $\alpha$ on bone formation in female mice. The observations that ER- $\alpha$ and ER- $\beta$ play opposing roles in cortical bones are further corroborated by studies that show that female ERKOneo2 mice have shorter bones than female DERKOki animals (ERKOneo2/BERKOki), ${ }^{111,112}$ while BERKOki females show an increase in femur length. ${ }^{118}$ In agreement with the above reports, Sims et al using another BERKO mouse developed at Strasbourg, France, ${ }^{105}$ showed an increase in femur length $(15.3 \pm 0.1 \mathrm{~mm}$ in WT vs $15.9 \pm 0.2 \mathrm{~mm}$ in BERKOst) in female mice (16 weeks), while in the BERKOst females, decreased bone resorption and a resultant increase in trabecular bone volume were observed. ${ }^{107}$ However, in contrast to the studies with DERKOki mice which show intermediate femur length to ERKOneo2 and BERKOki, Sims et al using DERKOst mice (ERKOd3/BERKOst) observed decreased femur length, equivalent to BERKOst animals. ${ }^{107}$ Further, a profound decrease in trabecular bone volume in DERKOst females was associated with a decrease in bone turnover. ${ }^{107}$ Together, the knockout mice model studies suggest that ER- $\alpha$ and ER- $\beta$ may play opposing roles in cortical bone growth in young adults and a compensatory role in trabecular bone turnover in aged mice.

Female ERKO mice have decreased femur length, and this decrease is associated with a decrease in serum levels of IGF-1. ${ }^{109}$ In addition, BERKO mice displayed an increased length of femur, and this was found to be associated with an increase of serum levels of IGF-1. ${ }^{113}$ Interestingly, in female DERKO mice, the length of femur and serum levels of IGF-1 were intermediate between ERKO and BERKO mice. ${ }^{112}$ The GH/IGF-1 axis might be involved in the estrogenic regulation of appendicular bone growth because the serum IGF-1 levels were strongly correlated with the femur length in the mice with ER inactivation. ${ }^{12}$ These data clearly demonstrate that ER- $\alpha$ and ER- $\beta$ have opposing effects on appendicular growth in female mice. It is thus proposed that while ER- $\alpha$ promotes longitudinal bone growth in female mice, ER- $\beta$ represses it.

The molecular mechanisms of action for ER- $\alpha$ versus ER- $\beta$ have recently been investigated. ER- $\alpha$ and ER- $\beta$ have almost identical DNA-binding domains, and studies in vitro have demonstrated that the two receptors share some similarities in the affinity for estrogenic compounds. ${ }^{120,121}$ The amino acid sequence of ER- $\beta$ differs from ER- $\alpha$ in the NH2- and $\mathrm{COOH}$-terminal transactivating regions. This suggests that the transcriptional activation mediated by ER- $\beta$ is distinct from that of ER- $\alpha^{122}$ Owing to the significant similarities in DNA-binding specificity, it is speculated that a differential tissue distribution of ERs may play an important role in mediating tissue-specific responses to estrogens. ${ }^{123}$ Hence, the unique transactivating domains of the two receptor subtypes along with differential tissue distribution may be important factors in determining the estrogen response in target tissues.

\section{ERs and the male skeleton}

It is well documented that men gain more bone than women during puberty ${ }^{124,125}$ with periosteum appearing to be the major site for bone acquisition. ${ }^{109}$ Greater periosteal bone expansion in men accompanied by less endocortical expansion has been assumed to result from exposure to higher levels of androgens and lower levels of estrogens. ${ }^{90}$ During prepubertal growth, periosteal apposition increases bone width in both sexes. In pubertal males, periosteal diameter 
continues to expand, but when females enter puberty, this process is inhibited. ${ }^{126}$ The larger cortical bone size in males compared with females is due to differences in sex steroid exposure during sexual maturation. ${ }^{126}$ Studies in male $\mathrm{AR}^{-/-}$ mice have clearly demonstrated that AR activation results in cortical radial bone expansion. ${ }^{127}$ It has been suggested that men are more exposed to the stimulatory effects of androgens and less exposed to the inhibitory effects of estrogens, which is not the case in women. ${ }^{125}$ Androgens may primarily affect lean body mass and the loading of the male skeleton, and exposure to low-dose estrogen may allow this loading to induce bone expansion. ${ }^{103}$ However, androgens alone are insufficient to drive male periosteal bone formation. ${ }^{90}$

The effect of androgens on the male skeleton may be either direct through a stimulation of ARs or indirect through aromatization of androgens into estrogen and stimulation of ERs. ${ }^{109}$ However, it has been clearly demonstrated that the effect of androgens on the male skeleton, at least partly, depends on the conversion of androgens into estrogen. ${ }^{109}$ It has been demonstrated that loss of ERs leading to estrogen resistance in the male mouse results in decreased longitudinal as well as radial skeletal growth. ${ }^{109}$ Repressed growth is found in ERKO males resulting in shorter long bones. ${ }^{90,109}$ Studies with ERKOd3 mice, considered as ER- $\alpha$-null, ${ }^{106}$ revealed that these mice exhibit a decrease in bone turnover and an increase in trabecular bone volume in male animals; while there was no effect on femoral bone lengths in males, these mice revealed a decreased thickness of cortical bone. ${ }^{107}$ ERKOneo2 mice, in contrast, showed clear stimulatory effect of ER- $\alpha$ on bone length in male. ${ }^{109,110}$ However, no effect is seen in BERKO males unlike in females. Male ER- $\alpha^{-/-}$but not ER- $\beta^{-/-}$mice displayed reduced cortical radial bone growth during sexual maturation, thus demonstrating that it is ER- $\alpha$ and not ER- $\beta$ activation that is required for a normal cortical radial bone expansion in males during growth. ${ }^{90}$ In the male BERKOst mice models, ${ }^{105}$ no effect was found on femur length (16 weeks).

The shortening of the long bones in ERKO and DERKO mice is associated with decreased growth plate width in the proximal tibia. ${ }^{90}$ Furthermore, Ornoy et al ${ }^{128}$ showed that orchidectomy in mice decreases growth plate area measured in the proximal tibia and that low-dose estrogen treatment increases the same parameter. These findings demonstrate that physiological levels of estrogen have a stimulatory effect on longitudinal growth in male rodents. Similarly, estrogens are required for the pubertal growth spurt in boys. ${ }^{129}$ Estrogen regulates final height in humans by a stimulatory effect on the pubertal growth spurt, followed by closure of the epiphyseal growth plates at the end of puberty.

As the cortical radial bone growth is reduced during sexual maturation in the male ER- $\alpha^{-/-}$mice, it is speculated that the GH/IGF-1 axis is involved in this effect. A major part of serum IGF-1 is liver-derived, and it is seen that male ER- $\alpha^{-/-}$mice had a cortical bone phenotype similar to mice with liverspecific IGF-1 inactivation. ${ }^{109,126,130}$ Importantly, serum IGF-1 levels were reduced in the ER- $\alpha^{-/-}$mice, suggesting that these decreased serum IGF-1 levels might mediate the reduced cortical radial bone growth seen in male ER- $\alpha^{-/-}$mice during sexual maturation. Thus, a normal pubertal cortical bone expansion in males might be dependent on an early ER- $\alpha$-mediated stimulation of the GH/IGF-1 axis. ${ }^{90}$ Interestingly, male DERKO mice follow the same growth pattern as male ERKO mice. This is in contrast to the intermediate growth seen in female DERKO mice. Thus, ER- $\beta$ represses longitudinal bone growth in female mice, while it has no function in the regulation of longitudinal bone growth in male mice. ${ }^{12}$

\section{Conclusion}

The GH/IGF-1 axis is critical to pubertal bone growth, and there exists a close interplay between estrogen and GH in the regulation of growth and development during puberty. Besides, sex steroids also have a direct action at the level of the growth plate. Both ER- $\alpha$ and ER- $\beta$ are expressed in the growth plate as well as in the bone, suggesting a role for both ER subtypes in the regulation of skeletal homeostasis. From studies of individuals with aromatase deficiency and defective ER- $\alpha$, it has become clear that the action of estrogen is indispensable for normal pubertal growth and growth plate fusion. There is abundant evidence that estrogen is essential for normal pubertal growth and epiphyseal maturation in not only females but also in males. Androgens alone are insufficient to drive periosteal bone formation. In fact, androgens augment pubertal growth and stimulate growth factor production at the growth plate by aromatization to estrogen. Consequently, estradiol should not be regarded exclusively as a 'female hormone', but as a sex steroid that is necessary for maintenance of bone health and perhaps other physiological functions in both males and females.

\section{Acknowledgments}

The authors are grateful to Ministry of Health and Family Welfare and Council of Scientific and Industrial Research, Government of India. DS contributed in the compilation of literature and wrote part of the review. SS contributed significantly in the sections dealing with estrogen receptor 
signaling and ER knockout studies. NC summarized the whole study.

\section{Disclosure}

The authors report no conflicts of interest in this work.

\section{References}

1. Tuck SP, Francis RM. Osteoporosis. Postgrad Med J. 2002; 78(923):526-532.

2. Cooper C, Emkey RD, McDonald RH, et al. Efficacy and safety of oral weekly ibandronate in the treatment of postmenopausal osteoporosis. J Clin Endocrinol Metab. 2003;88(10):4609-4615.

3. Bonjour JP, Ammann P, Chevalley T, Rizzoli R. Protein intake and bone growth. Can J Appl Physiol. 2001;26 Suppl:S153-S166.

4. Bonjour JP, Chevalley T, Ferrari S, Rizzoli R. The importance and relevance of peak bone mass in the prevalence of osteoporosis. Salud Publica Mex. 2009;51 Suppl 1:S5-S17.

5. Theintz G, Buchs B, Rizzoli R, et al. Longitudinal monitoring of bone mass accumulation in healthy adolescents: evidence for a marked reduction after 16 years of age at the levels of lumbar spine and femoral neck in female subjects. J Clin Endocrinol Metab. 1992;75(4): 1060-1065.

6. Melton LJ 3rd, Looker AC, Shepherd JA, et al. Osteoporosis assessment by whole body region vs site-specific DXA. Osteoporos Int. 2005; 16(12):1558-1564.

7. Bass S, Delmas PD, Pearce G, Hendrich E, Tabensky A, Seeman E. The differing tempo of growth in bone size, mass, and density in girls is region-specific. J Clin Invest. 1999;104(6):795-804.

8. Kanis JA. Assessment of fracture risk and its application to screening for postmenopausal osteoporosis: synopsis of a WHO report. WHO Study Group. Osteoporos Int. 1994;4(6):368-381.

9. Hansen MA, Overgaard K, Riis BJ, Christiansen C. Role of peak bone mass and bone loss in postmenopausal osteoporosis: 12 year study. BMJ. 1991;303(6808):961-964.

10. Briot K, Roux C. What is the role of DXA, QUS and bone markers in fracture prediction, treatment allocation and monitoring? Best Pract Res Clin Rheumatol. 2005;19(6):951-964.

11. Ferrari S, Manen D, Bonjour JP, Slosman D, Rizzoli R. Bone mineral mass and calcium and phosphate metabolism in young men: relationships with vitamin $\mathrm{D}$ receptor allelic polymorphisms. J Clin Endocrinol Metab. 1999;84(6):2043-2048.

12. Ferrari S, Rizzoli R, Manen D, Slosman D, Bonjour JP. Vitamin D receptor gene start codon polymorphisms (FokI) and bone mineral density: interaction with age, dietary calcium, and 3 '-end region polymorphisms. J Bone Miner Res. 1998;13(6):925-930.

13. Bonjour JP, Theintz G, Law F, Slosman D, Rizzoli R. Peak bone mass. Osteoporos Int. 1994;4(Suppl 1):7-13.

14. Hasegawa Y, Schneider P, Reiners C, et al. Estimation of the architectural properties of cortical bone using peripheral quantitative computed tomography. Osteoporos Int. 2000;11(1):36-42.

15. Riggs BL, Khosla S, Melton LJ 3rd. Sex steroids and the construction and conservation of the adult skeleton. Endocr Rev. 2002;23(3): 279-302.

16. Lu PW, Cowell CT, LLoyd-Jones SA, Briody JN, Howman-Giles R. Volumetric bone mineral density in normal subjects, aged 5-27 years. J Clin Endocrinol Metab. 1996;81(4):1586-1590.

17. Cadogan J, Blumsohn A, Barker ME, Eastell R. A longitudinal study of bone gain in pubertal girls: anthropometric and biochemical correlates. J Bone Miner Res. 1998;13(10):1602-1612.

18. Terasawa E, Fernandez DL. Neurobiological mechanisms of the onset of puberty in primates. Endocr Rev. 2001;22(1):111-151.

19. Magarey AM, Boulton TJ, Chatterton BE, Schultz C, Nordin BE, Cockington RA. Bone growth from 11 to 17 years: relationship to growth, gender and changes with pubertal status including timing of menarche. Acta Paediatr. 1999;88(2):139-146.
20. Vizmanos B, Martí-Henneberg C, Clivillé R, Moreno A, Fernández-Ballart J. Age of pubertal onset affects the intensity and duration of pubertal growth peak but not final height. Am J Hum Biol. 2001;13(3): 409-416.

21. Riggs BL, Khosla S, Melton LJ 3rd. The assembly of the adult skeleton during growth and maturation: implications for senile osteoporosis. J Clin Invest. 1999;104(6):671-672.

22. Duan Y, Beck TJ, Wang XF, Seeman E. Structural and biomechanical basis of sexual dimorphism in femoral neck fragility has its origins in growth and aging. J Bone Miner Res. 2003;18(10):1766-1774.

23. Seeman E. Periosteal bone formation - a neglected determinant of bone strength. N Engl J Med. 2003;349(4):320-323.

24. Seeman E. Clinical review 137: sexual dimorphism in skeletal size, density, and strength. J Clin Endocrinol Metab. 2001;86(10):4576-4584.

25. Kontulainen SA, Macdonald HM, Khan KM, McKay HA. Examining bone surfaces across puberty: a 20-month pQCT trial. J Bone Miner Res. 2005;20(7):1202-1207.

26. Seeman E. Invited review: pathogenesis of osteoporosis. J Appl Physiol. 2003;95(5):2142-2151.

27. Seeman E. Bone quality. Osteoporos Int. 2003;14(Suppl 5):S3-S7.

28. Seeman E. Pathogenesis of bone fragility in women and men. Lancet. 2002;359(9320):1841-1850.

29. Vanderschueren D, Vandenput L, Boonen S. Reversing sex steroid deficiency and optimizing skeletal development in the adolescent with gonadal failure. Endocr Dev. 2005;8:150-165.

30. Heaney RP, Abrams S, Dawson-Hughes B, et al. Peak bone mass. Osteoporos Int. 2000;11(12):985-1009.

31. Wosje KS, Specker BL. Role of calcium in bone health during childhood. Nutr Rev. 2000;58(9):253-268.

32. Masuyama R, Nakaya Y, Katsumata S, et al. Dietary calcium and phosphorus ratio regulates bone mineralization and turnover in vitamin $\mathrm{D}$ receptor knockout mice by affecting intestinal calcium and phosphorus absorption. J Bone Miner Res. 2003;18(7):1217-1226.

33. Estívariz CF, Ziegler TR. Nutrition and the insulin-like growth factor system. Endocrine. 1997;7(1):65-71.

34. Christoforidis A, Maniadaki I, Stanhope R. Growth hormone/ insulin-like growth factor-1 axis during puberty. Pediatr Endocrinol Rev. 2005;3(1):5-10.

35. Mauras N. Growth hormone and sex steroids. Interactions in puberty. Endocrinol Metab Clin North Am. 2001;30(3):529-544.

36. Clark PA, Rogol AD. Growth hormones and sex steroid interactions at puberty. Endocrinol Metab Clin North Am. 1996;25(3):665-681.

37. Styne DM. The regulation of pubertal growth. Horm Res. 2003;60(Suppl 1):22-26.

38. Juul A, Bang P, Hertel NT, et al. Serum insulin-like growth factor-I in 1030 healthy children, adolescents, and adults: relation to age, sex, stage of puberty, testicular size, and body mass index. JClin Endocrinol Metab. 1994;78(3):744-752.

39. Albertsson-Wikland K, Rosberg S, Karlberg J, Groth T. Analysis of 24-hour growth hormone profiles in healthy boys and girls of normal stature: relation to puberty. J Clin Endocrinol Metab. 1994; 78(5):1195-1201.

40. Giustina A, Scalvini T, Tassi C, et al. Maturation of the regulation of growth hormone secretion in young males with hypogonadotropic hypogonadism pharmacologically exposed to progressive increments in serum testosterone. J Clin Endocrinol Metab. 1997;82(4):1210-1219.

41. Marin G, Domené HM, Barnes KM, Blackwell BJ, Cassorla FG, Cutler GB Jr. The effects of estrogen priming and puberty on the growth hormone response to standardized treadmill exercise and arginine-insulin in normal girls and boys. J Clin Endocrinol Metab. 1994;79(2):537-541.

42. Leung KC, Johannsson G, Leong GM, Ho KK. Estrogen regulation of growth hormone action. Endocr Rev. 2004;25(5):693-721.

43. Juul A. The effects of oestrogens on linear bone growth. Hum Reprod Update. 2001;7(3):303-313.

44. Frank GR. Role of estrogen and androgen in pubertal skeletal physiology. Med Pediatr Oncol. 2003;41(3):217-221. 
45. Meinhardt UJ, Ho KK. Modulation of growth hormone action by sex steroids. Clin Endocrinol (Oxf). 2006;65(4):413-422.

46. Chagin AS, Sävendahl L. Genes of importance in the hormonal regulation of growth plate cartilage. Horm Res. 2009;71 Suppl 2:41-47.

47. Veldhuis JD, Roemmich JN, Rogol AD. Gender and sexual maturation-dependent contrasts in the neuroregulation of growth hormone secretion in prepubertal and late adolescent males and females - a general clinical research center-based study. J Clin Endocrinol Metab. 2000;85(7):2385-2394.

48. Coutant R, de Casson FB, Rouleau S, et al. Divergent effect of endogenous and exogenous sex steroids on the insulin-like growth factor I response to growth hormone in short normal adolescents. $J$ Clin Endocrinol Metab. 2004;89(12):6185-6192.

49. Metzger DL, Kerrigan JR, Rogol AD. Gonadal steroid hormone regulation of the somatotropic axis during puberty in humans mechanisms of androgen and estrogen action. Trends Endocrinol Metab. 1994;5(7):290-296.

50. Metzger DL, Kerrigan JR. Estrogen receptor blockade with tamoxifen diminishes growth hormone secretion in boys: evidence for a stimulatory role of endogenous estrogens during male adolescence. $J$ Clin Endocrinol Metab. 1994;79(2):513-518.

51. Hero M, Norjavaara E, Dunkel L. Inhibition of estrogen biosynthesis with a potent aromatase inhibitor increases predicted adult height in boys with idiopathic short stature: a randomized controlled trial. J Clin Endocrinol Metab. 2005;90(12):6396-6402.

52. Mauras N, Gonzalez de Pijem L, Hsiang HY, et al. Anastrozole increases predicted adult height of short adolescent males treated with growth hormone: a randomized, placebo-controlled, multicenter trial for one to three years. J Clin Endocrinol Metab. 2008;93(3):823-831.

53. Wennink JM, Delemarre-van de Waal HA, Schoemaker R, Blaauw G, van den Braken C, Schoemaker J. Growth hormone secretion patterns in relation to $\mathrm{LH}$ and testosterone secretion throughout normal male puberty. Acta Endocrinol (Copenh). 1990;123(3):263-270.

54. Ho KY, Evans WS, Blizzard RM, et al. Effects of sex and age on the 24-hour profile of growth hormone secretion in man: importance of endogenous estradiol concentrations. J Clin Endocrinol Metab. 1987;64(1):51-58.

55. Winer LM, Shaw MA, Baumann G. Basal plasma growth hormone levels in man: new evidence for rhythmicity of growth hormone secretion. J Clin Endocrinol Metab. 1990;70(6):1678-1686.

56. Laron Z, Lilos P, Klinger B. Growth curves for Laron syndrome. Arch Dis Child. 1993;68(6):768-770.

57. Keenan BS, Richards GE, Ponder SW, Dallas JS, Nagamani M, Smith ER. Androgen-stimulated pubertal growth: the effects of testosterone and dihydrotestosterone on growth hormone and insulin-like growth factor-I in the treatment of short stature and delayed puberty. J Clin Endocrinol Metab. 1993;76(4):996-1001.

58. Eakman GD, Dallas JS, Ponder SW, Keenan BS. The effects of testosterone and dihydrotestosterone on hypothalamic regulation of growth hormone secretion. J Clin Endocrinol Metab. 1996;81(3):1217-1223.

59. Veldhuis JD, Metzger DL, Martha PM Jr, et al. Estrogen and testosterone, but not a nonaromatizable androgen, direct network integration of the hypothalamo-somatotrope (growth hormone)-insulin-like growth factor I axis in the human: evidence from pubertal pathophysiology and sex-steroid hormone replacement. J Clin Endocrinol Metab. 1997; 82(10):3414-3420.

60. Weissberger AJ, Ho KK. Activation of the somatotropic axis by testosterone in adult males: evidence for the role of aromatization. J Clin Endocrinol Metab. 1993;76(6):1407-1412.

61. Ulloa-Aguirre A, Blizzard RM, Garcia-Rubi E, et al. Testosterone and oxandrolone, a nonaromatizable androgen, specifically amplify the mass and rate of growth hormone $(\mathrm{GH})$ secreted per burst without altering GH secretory burst duration or frequency or the GH half-life. $J$ Clin Endocrinol Metab. 1990;71(4):846-854.

62. Malhotra A, Poon E, Tse WY, Pringle PJ, Hindmarsh PC, Brook CG. The effects of oxandrolone on the growth hormone and gonadal axes in boys with constitutional delay of growth and puberty. Clin Endocrinol (Oxf). 1993;38(4):393-398.
63. Crowne EC, Wallace WH, Moore C, et al. Effect of low dose oxandrolone and testosterone treatment on the pituitary-testicular and $\mathrm{GH}$ axes in boys with constitutional delay of growth and puberty. Clin Endocrinol (Oxf). 1997;46(2):209-216.

64. Vanderschueren D, Vandenput L, Boonen S, Lindberg MK, Bouillon R, Ohlsson C. Androgens and bone. Endocr Rev. 2004;25(3): 389-425.

65. Simm PJ, Bajpai A, Russo VC, Werther GA. Estrogens and growth. Pediatr Endocrinol Rev. 2008;6(1):32-41.

66. Weise M, de-Levi S, Barnes KM, Gafni RI, Abad V, Baron J. Effects of estrogen on growth plate senescence and epiphyseal fusion. Proc Natl Acad Sci U S A. 2001;98(12):6871-6876.

67. Hunziker EB, Schenk RK. Physiological mechanisms adopted by chondrocytes in regulating longitudinal bone growth in rats. $J$ Physiol. 1989;414:55-71.

68. Simpson E, Rubin G, Clyne C, et al. Local estrogen biosynthesis in males and females. Endocr Relat Cancer. 1999;6(2):131-137.

69. Morishima A, Grumbach MM, Simpson ER, Fisher C, Qin K. Aromatase deficiency in male and female siblings caused by a novel mutation and the physiological role of estrogens. J Clin Endocrinol Metab. 1995;80(12):3689-3698.

70. Smith EP, Boyd J, Frank GR, et al. Estrogen resistance caused by a mutation in the estrogen-receptor gene in a man. N Engl J Med. 1994; 331(16):1056-1061.

71. Brown TR, Lubahn DB, Wilson EM, French FS, Migeon CJ, Corden JL. Functional characterization of naturally occurring mutant androgen receptors from subjects with complete androgen insensitivity. Mol Endocrinol. 1990;4(12):1759-1772.

72. Ritzén EM. Pubertal growth in genetic disorders of sex hormone action and secretion. Acta Paediatr Suppl. 1992;383:22-25; discussion 26.

73. Conte FA, Grumbach MM, Ito Y, Fisher CR, Simpson ER. A syndrome of female pseudohermaphrodism, hypergonadotropic hypogonadism, and multicystic ovaries associated with missense mutations in the gene encoding aromatase (P450arom). J Clin Endocrinol Metab. 1994; 78(6):1287-1292.

74. Hochberg Z, Schechter J, Benderly A, Leiberman E, Rosler A. Growth and pubertal development in patients with congenital adrenal hyperplasia due to 11-beta-hydroxylase deficiency. Am J Dis Child. 1985; 139(8):771-776.

75. Compston JE. Sex steroids and bone. Physiol Rev. 2001;81(1): 419-447.

76. Laue L, Kenigsberg D, Pescovitz OH, et al. Treatment of familial male precocious puberty with spironolactone and testolactone. $N$ Engl J Med. 1989;320(8):496-502.

77. Bilezikian JP, Morishima A, Bell J, Grumbach MM. Increased bone mass as a result of estrogen therapy in a man with aromatase deficiency. N Engl J Med. 1998;339(9):599-603.

78. Gilsanz V, Skaggs DL, Kovanlikaya A, et al. Differential effect of race on the axial and appendicular skeletons of children. J Clin Endocrinol Metab. 1998;83(5):1420-1427.

79. Gilsanz V, Kovanlikaya A, Costin G, Roe TF, Sayre J, Kaufman F. Differential effect of gender on the sizes of the bones in the axial and appendicular skeletons. J Clin Endocrinol Metab. 1997;82(5): $1603-1607$.

80. Iuliano-Burns S, Hopper J, Seeman E. The age of puberty determines sexual dimorphism in bone structure: a male/female co-twin control study. J Clin Endocrinol Metab. 2009;94(5):1638-1643.

81. Bradney M, Karlsson MK, Duan Y, Stuckey S, Bass S, Seeman E. Heterogeneity in the growth of the axial and appendicular skeleton in boys: implications for the pathogenesis of bone fragility in men. $J$ Bone Miner Res. 2000;15(10):1871-1878.

82. Seeman E. Growth in bone mass and size - are racial and gender differences in bone mineral density more apparent than real? J Clin Endocrinol Metab. 1998;83(5):1414-1419.

83. Gilsanz V, Roe TF, Mora S, Costin G, Goodman WG. Changes in vertebral bone density in black girls and white girls during childhood and puberty. N Engl J Med. 1991;325(23):1597-1600. 
84. Bryant RJ, Wastney ME, Martin BR, et al. Racial differences in bone turnover and calcium metabolism in adolescent females. J Clin Endocrinol Metab. 2003;88(3):1043-1047.

85. Windahl SH, Lagerquist MK, Andersson N, et al. Identification of target cells for the genomic effects of estrogens in bone. Endocrinology. 2007;148(12):5688-5695.

86. Kusec V, Virdi AS, Prince R, Triffitt JT. Localization of estrogen receptor-alpha in human and rabbit skeletal tissues. J Clin Endocrinol Metab. 1998;83(7):2421-2428.

87. Nilsson LO, Boman A, Sävendahl L, et al. Demonstration of estrogen receptor-beta immunoreactivity in human growth plate cartilage. J Clin Endocrinol Metab. 1999;84(1):370-373.

88. Arts J, Kuiper GG, Janssen JM, et al. Differential expression of estrogen receptors alpha and beta mRNA during differentiation of human osteoblast SV-HFO cells. Endocrinology. 1997;138(11): 5067-5070

89. Chagin AS, Vannesjö J, Sävendahl L. Androgen receptor modulation does not affect longitudinal growth of cultured fetal rat metatarsal bones. Horm Res. 2009;71(4):219-227.

90. Ohlsson C, Vandenput L. The role of estrogens for male bone health. Eur J Endocrinol. 2009;160(6):883-889.

91. Chagin AS, Sävendahl L. GPR30 estrogen receptor expression in the growth plate declines as puberty progresses. J Clin Endocrinol Metab 2007;92(12):4873-4877.

92. Krassas GE, Papadopoulou P. Oestrogen action on bone cells. J Musculoskelet Neuronal Interact. 2001;2(2):143-151.

93. Nakamura T, Imai Y, Matsumoto T, et al. Estrogen prevents bone loss via estrogen receptor alpha and induction of Fas ligand in osteoclasts. Cell. 2007;130(5):811-823.

94. Krum SA, Miranda-Carboni GA, Hauschka PV, et al. Estrogen protects bone by inducing Fas ligand in osteoblasts to regulate osteoclast survival. EMBO J. 2008;27(3):535-545.

95. García Palacios V, Robinson LJ, Borysenko CW, Lehmann T, Kalla SE, Blair HC. Negative regulation of RANKL-induced osteoclastic differentiation in RAW264.7 cells by estrogen and phytoestrogens. J Biol Chem. 2005;280(14):13720-13727.

96. Komm BS, Terpening CM, Benz DJ, et al. Estrogen binding, receptor mRNA, and biologic response in osteoblast-like osteosarcoma cells. Science. 1988;241(4861):81-84.

97. Khastgir G, Studd J, Holland N, Alaghband-Zadeh J, Fox S, Chow J. Anabolic effect of estrogen replacement on bone in postmenopausal women with osteoporosis: histomorphometric evidence in a longitudinal study. J Clin Endocrinol Metab. 2001;86(1):289-295.

98. Nasu M, Sugimoto T, Kaji H, Chihara K. Estrogen modulates osteoblast proliferation and function regulated by parathyroid hormone in osteoblastic SaOS-2 cells: role of insulin-like growth factor (IGF)-I and IGF-binding protein-5. J Endocrinol. 2000;167(2):305-313.

99. Okazaki R, Inoue D, Shibata M, et al. Estrogen promotes early osteoblast differentiation and inhibits adipocyte differentiation in mouse bone marrow stromal cell lines that express estrogen receptor (ER) alpha or beta. Endocrinology. 2002;143(6): 2349-2356.

100. Zhou S, Turgeman G, Harris SE, et al. Estrogens activate bone morphogenetic protein-2 gene transcription in mouse mesenchymal stem cells. Mol Endocrinol. 2003;17(1):56-66.

101. Perry RJ, Farquharson C, Ahmed SF. The role of sex steroids in controlling pubertal growth. Clin Endocrinol (Oxf). 2008;68(1):4-15.

102. Chagin AS, Sävendahl L. Estrogens and growth: review. Pediatr Endocrinol Rev. 2007;4(4):329-334.

103. Vanderschueren D, Venken K, Ophoff J, Bouillon R, Boonen S. Clinical review: sex steroids and the periosteum - reconsidering the roles of androgens and estrogens in periosteal expansion. J Clin Endocrinol Metab. 2006;91(2):378-382.

104. Lubahn DB, Moyer JS, Golding TS, Couse JF, Korach KS, Smithies O. Alteration of reproductive function but not prenatal sexual development after insertional disruption of the mouse estrogen receptor gene. Proc Natl Acad Sci U S A. 1993;90(23):11162-11166.
105. Dupont S, Krust A, Gansmuller A, Dierich A, Chambon P, Mark M. Effect of single and compound knockouts of estrogen receptors alpha (ERalpha) and beta (ERbeta) on mouse reproductive phenotypes. Development. 2000;127(19):4277-4291.

106. Pendaries C, Darblade B, Rochaix P, et al. The AF-1 activation-function of ERalpha may be dispensable to mediate the effect of estradiol on endothelial NO production in mice. Proc Natl Acad Sci U S A. 2002; 99(4):2205-2210.

107. Sims NA, Dupont S, Krust A, et al. Deletion of estrogen receptors reveals a regulatory role for estrogen receptors-beta in bone remodeling in females but not in males. Bone. 2002;30(1):18-25.

108. Tözüm TF, Oppenlander ME, Koh-Paige AJ, Robins DM, McCauley LK. Effects of sex steroid receptor specificity in the regulation of skeletal metabolism. Calcif Tissue Int. 2004;75(1):60-70.

109. Vidal O, Lindberg MK, Hollberg K, et al. Estrogen receptor specificity in the regulation of skeletal growth and maturation in male mice. Proc Natl Acad Sci U S A. 2000;97(10):5474-5479.

110. Parikka V, Peng Z, Hentunen T, et al. Estrogen responsiveness of bone formation in vitro and altered bone phenotype in aged estrogen receptor-alpha-deficient male and female mice. Eur J Endocrinol. 2005;152(2):301-314.

111. Chagin AS, Lindberg MK, Andersson N, et al. Estrogen receptor-beta inhibits skeletal growth and has the capacity to mediate growth plate fusion in female mice. J Bone Miner Res. 2004;19(1):72-77.

112. Lindberg MK, Alatalo SL, Halleen JM, Mohan S, Gustafsson JA, Ohlsson C. Estrogen receptor specificity in the regulation of the skeleton in female mice. J Endocrinol. 2001;171(2):229-236.

113. Windahl SH, Vidal O, Andersson G, Gustafsson JA, Ohlsson C. Increased cortical bone mineral content but unchanged trabecular bone mineral density in female ERbeta(-/-) mice. J Clin Invest. 1999;104(7): 895-901.

114. Flouriot G, Brand H, Denger S, et al. Identification of a new isoform of the human estrogen receptor-alpha (hER-alpha) that is encoded by distinct transcripts and that is able to repress hER-alpha activation function 1. EMBO J. 2000;19(17):4688-4700.

115. Chagin A, Nilsson M, Dahlman Wright K, Sävendahl L. Remaining estrogenic activity in the man with mutated estrogen receptor alpha (ERa). Horm Res. 2006;65 Suppl 4:28.

116. Vidal O, Lindberg M, Sävendahl L, et al. Disproportional body growth in female estrogen receptor-alpha-inactivated mice. Biochem Biophys Res Commun. 1999;265(2):569-571.

117. Krege JH, Hodgin JB, Couse JF, et al. Generation and reproductive phenotypes of mice lacking estrogen receptor beta. Proc Natl Acad Sci U S A. 1998;95(26):15677-15682.

118. Ke HZ, Brown TA, Qi H, et al. The role of estrogen receptor-beta, in the early age-related bone gain and later age-related bone loss in female mice. J Musculoskelet Neuronal Interact. 2002;2(5):479-488.

119. Windahl SH, Hollberg K, Vidal O, Gustafsson JA, Ohlsson C, Andersson G. Female estrogen receptor beta(-/-) mice are partially protected against age-related trabecular bone loss. J Bone Miner Res. 2001;16(8):1388-1398.

120. Kuiper GG, Enmark E, Pelto-Huikko M, Nilsson S, Gustafsson JA. Cloning of a novel receptor expressed in rat prostate and ovary. Proc Natl Acad Sci U S A. 1996;93(12):5925-5930.

121. Kuiper GG, Carlsson B, Grandien K, et al. Comparison of the ligand binding specificity and transcript tissue distribution of estrogen receptors alpha and beta. Endocrinology. 1997;138(3):863-870.

122. Paech K, Webb P, Kuiper GG, et al. Differential ligand activation of estrogen receptors ERalpha and ERbeta at AP1 sites. Science. 1997 277(5331):1508-1510.

123. Kuiper GG, Gustafsson JA. The novel estrogen receptor-beta subtype: potential role in the cell- and promoter-specific actions of estrogens and anti-estrogens. FEBS Lett. 1997;410(1):87-90.

124. Revankar CM, Cimino DF, Sklar LA, Arterburn JB, Prossnitz ER. A transmembrane intracellular estrogen receptor mediates rapid cell signaling. Science. 2005;307(5715): $1625-1630$. 
125. Vidal O, Kindblom LG, Ohlsson C. Expression and localization of estrogen receptor-beta in murine and human bone. J Bone Miner Res. 1999;14(6):923-929.

126. Yakar S, Liu JL, Stannard B, et al. Normal growth and development in the absence of hepatic insulin-like growth factor I. Proc Natl Acad Sci U S A. 1999;96(13):7324-7329.

127. Venken K, de Gendt K, Boonen S, et al. Relative impact of androgen and estrogen receptor activation in the effects of androgens on trabecular and cortical bone in growing male mice: a study in the androgen receptor knockout mouse model. J Bone Miner Res. 2006; 21(4):576-585.
128. Ornoy A, Giron S, Aner R, Goldstein M, Boyan BD, Schwartz Z. Gender dependent effects of testosterone and 17 beta-estradiol on bone growth and modelling in young mice. Bone Miner. 1994;24(1):43-58.

129. MacGillivray MH, Morishima A, Conte F, Grumbach M, Smith EP. Pediatric endocrinology update: an overview. The essential roles of estrogens in pubertal growth, epiphyseal fusion and bone turnover: lessons from mutations in the genes for aromatase and the estrogen receptor. Horm Res. 1998;49 Suppl 1:2-8.

130. Yakar S, Rosen CJ, Beamer WG, et al. Circulating levels of IGF-1 directly regulate bone growth and density. J Clin Invest. 2002;110(6): 771-781.

\section{Publish your work in this journal}

Cell Health and Cytoskeleton is an international, peer-reviewed open access journal focusing on all aspects of cell structure and function contributing to normal physiology and cell health and exploring the pathogenesis of cell dysfunction leading to adverse conditions and disease in the organism. The journal welcomes papers covering original research,

\section{Dovepress}

basic science, reviews and evaluations, guidelines, expert opinion and commentary, case reports and extended reports. The manuscript management system is completely online and includes a very quick and fair peer-review system, which is all easy to use. Visit http://www.dovepress. com/testimonials.php to read real quotes from published authors. 